\title{
THE ACCEPTANCE OF ICT BY TEACHERS AND ITS DEVELOPMENT BETWEEN 2004 AND 2015
}

\author{
Miroslav CHRÁSKA*, Univerzita Palackého v Olomouci
}

Přijato: 3. 11. 2015 / Akceptováno: 27. 11. 2015

Typ článku: Výzkum

DOI: $10.5507 /$ jtie.2015.013

Abstract: The paper describes the results of a comparative research study of elementary school teachers' attitudes to ICT between 2004 and 2015. Teachers indicated their attitude to ICT by selecting from a six-degree scale ranging from agreement to disagreement. Teachers' replies in the monitored years were statistically processed including a cluster analysis. The results indicate an anticipated positive shift towards more intensive ICT use, improved virtual communication and use of the internet. According to their consent indicated for various statements, teachers can be divided into two different groups - clusters.

Key words: teachers' attitudes to ICT, comparative research, scale ranging, cluster analysis.

\section{AKCEPTACE INFORMAČNÍCH A KOMUNIKAČNÍCH TECHNOLOGIÍ UČITELI A JEJÍ VÝVOJ MEZI ROKY 2004 A 2015}

Resumé: Článek popisuje výsledky srovnávacího výzkumu, který se zabýval tím, jak se změnil vztah učitelu základních škol k ICT mezi roky 2004 a 2015. Učitelé svi̊j vztah $k$ ICT vyjadřovali mírou souhlasu s vybranými tvrzeními na šestistupňové škále. Odpovédi učitelů ve sledovaných letech byly dále statisticky zpracovány včetně shlukové analýzy. Byl zjištěn předpokládaný pozitivní posun k intenzivnějšimu využiváni ICT, větši virtuální komunikaci a využivání Internetu. Ukázalo se také, že podle souhlasu s jednotlivými tvrzeními je možné učitele rozdělit do dvou odlišných skupin - shlukü.

Klíčová slova: vztah učitelů k ICT, srovnávací výzkum, škálové otázky, shluková analýza.

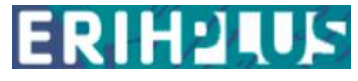

*Autor pro korespondenci: miroslav.chraska@upol.cz
This journal was approved on 2015-04-23 according to ERIH PLUS criteria for inclusion. 


\section{1 Úvod}

Od roku 2000, kdy byla vládou ČR schválena Koncepce státní informační politiky ve vzdělávání, se informační a komunikační technologie (dále jen ICT) staly postupně nedílnou součástí edukace na našich školách. Po prvních letech realizace této koncepce (tedy v roce 2004) nás zajímalo, jak jsou jednotlivé prvky zaváděných ICT vlastními učiteli přijímány (Chráska, 2004).

Jedním z východisek výzkumu pro vymezení možné typologie uživatelů ICT mezi učiteli na školách se stala Individual Innovativeness Theory (Černochová a kol., 2001), která vyjadřuje vztah mezi inovacemi a jejich aplikováním do vzdělávání. Teorie byla formulována $\mathrm{v} 80$. letech 20 . století a podle ní mohou být jedinci (a tedy i učitelé) rozděleni do pěti základních skupin, podle jejich př́stupu $\mathrm{k}$ inovacím a novinkám. Tyto kategorie tvoří: 1. „Novátor, zlepšovatel“ (nadšenec pro nové myšlenky), 2. „Ten, který si okamžitě osvojí novinky“ (dokáže předvídat), 3. „Jedinec, patř́íí $\mathrm{k}$ většině, která se vytvoří velmi brzy“ (pragmatik), 4. „Patřící k většině, která se utvoří až později“ (konzervativec, stavějící se proti novotám), 5. „Zaostalec“.

Dalším východiskem pro teoretické ukotvení výzkumu byly výsledky mezinárodního výzkumu SITES M2 (Law a kol., 2005), který zkoumal typické způsoby využití informačních a komunikačních technologií na školách $\mathrm{v}$ jednotlivých zemích zapojených do této etapy výzkumu.

Z výsledků našeho výzkumu však vyplynulo (Chráska, 2004), že české učitele je možné podle jejich typických způsobů práce s ICT rozdělit jen do dvou typických skupin. Rozdělení učitelů do pěti výše uvedených skupin tedy nebylo potvrzeno.

Dnes, $\mathrm{v}$ době, $\mathrm{kdy}$ si již nikdo $\mathrm{z}$ nás téměř nedovede představit fungování celé společnosti bez ICT, jsme se k výzkumu z roku 2004 znovu vrátili, abychom zjistili aktuální názory současných českých učitelů. Jsou spokojeni se současným stavem zaváděných ICT a jejich využívání nejen při přímé práci se žáky, ale i v rámci plnění svých dalších pracovních povinností? Došlo k výraznému posunu ve vztahu učitelů k ICT mezi roky 2004 a 2015? To jsou základní otázky, vedoucí nás k realizaci druhé fáze výzkumu. Navíc se oblasti výzkumu využití ICT v práci učitele - v České republice např. (Zounek, Šed’ová, 2009) - začala věnovat poměrně značná pozornost nejen aspektům původně relativně velkého očekávání od ICT, ale začala se sledovat i možná rizika tohoto masivního technologického posunu.

Ukazuje se, že samotná dostupnost technologií nemusí být zásadní pro jejich vlastní využití, např. (Tubin, 2012) a že používání ICT (včetně jejich organizačního začlenění) závisí více na pedagogických dovednostech učitele, než na technologích samotných. $\mathrm{V}$ tomto směru autor Tubin představuje čtyři typy př́stupů učitelů $\mathrm{k}$ využívání a integraci informačních a komunikačních technologií do výuky.

Podobně (Maria Mama, Hennessy, 2013) na základě výzkumu učitelů na Kypru uvádí, že omezené použití technologií ve tř́́dě lze vysvětlit nedostatkem vhodně zpracovaných didaktických postupů ve využití ICT v edukaci. Byla provedena multi-príípadová studie učitelů, zjištující chování učitelů vůči využití ICT a jejich zdůvodnění a na základě následné analýzy byly identifikovány čtyři typické skupiny učitelů.

Překvapivé výsledky přináší výzkum využití ICT u učitelů anglického jazyka v Korei (Webster, Son, 2015), který naznačuje, že využití technologií ve třídě může dokonce zhoršovat již existující pedagogické a infrastrukturní problémy. To může vést $\mathrm{k}$ nesrovnalostem $\mathrm{v}$ teoretickém i praktickém př́istupu ke způsobu využití ICT, což může $\mathrm{v}$ důsledku vyústit až $\mathrm{k}$ celkovému omezení potenciálního využití ICT učiteli ve výuce. 


\section{Cíl výzkumu}

Hlavním cílem provedeného srovnávacího výzkumu bylo zjistit posun názorů učitelů na využití informačních a komunikačních technologií v jejich vlastní práci v letech 2004 a 2015.

Dalším cílem výzkumu bylo ověření, zda se učitelé i v roce 2015 podle jejich názoru na ICT dělí do dvou základních skupin, stejně jako tomu bylo v roce 2004 (Chráska, 2004), či zda na základě provedené shlukové analýzy identifikujeme více charakteristických skupin učitelů.

\section{Použité výzkumné metody}

Jako výzkumná metoda byl v obou etapách srovnávacího výzkumu použit vlastní dotazník, ve kterém se učitelé vyjadřovali k 16 tvrzením. Míru svého souhlasu s jednotlivými tvrzeními učitelé vyjadřovali na šestistupňové škále (Chráska, 2004) s kódovanými odpověd'mi: zcela mne vystihuje (hodnota 6), vystihuje mne (5), spíše mne vystihuje (4), spíše mne nevystihuje (3), nevystihuje mne (2), zcela mne nevystihuje (1). Učitelé se $\mathrm{v}$ obou fázích výzkumu vyjadřovali $\mathrm{k}$ následujícím shodným tvrzením (pouze původní pojem výpočetní technika byl v roce 2015 doplněn pojmem informační/digitální technologie v souladu s terminologickým vývojem).

T1: Při své práci použíám Internet.

T2: Mám potíže s porozuměním novým programům, které mi dovolují provádět takové úkony, které jsem dosud nedělal(a).

T3: Nemám žádnou představu o využití výpočetní techniky (informačních/digitálních technologií).

T4: Informace z oblasti využití výpočetní techniky (informačních/digitálních technologií) umím vyhledávat na Internetu.

T5: Mám problémy $\mathrm{s}$ porozuměním novým počítačům (informačním/digitálním technologiím).

T6: Mám velmi dobré dovednosti v oblasti využití výpočetní techniky (informačních/digitálních technologií), dobře znám běžně použivané programy.

T7: Mám pocit, že v oblasti výpočetní techniky (informačních/digitálních technologií) nejsou žádné standardy.

T8: Neustále pracuji s lokálními a globálními sítěmi s využitím Internetu.

T9: Rychlost a nezastavitelný vývoj v oblasti výpočetní techniky (informačních/digitálních technologií) mne frustruje.

T10: Neustále vyhledávám nové možnosti využití výpočetní techniky (informačních/digitálních technologií).

T11: Pokud musím pracovat $\mathrm{s}$ výpočetní technikou (informačními/digitálními technologiemi), neustále žádám o technickou a mentální podporu.

T12: Spolupracuji s ostatními učiteli prostřednictvím počítačových sítí.

T13: Při své práci se snažím vždy používat výpočetní techniku (informační/digitální technologie).

T14: Pokud jsou pro můj předmět k dispozici výukové programy, vždy je používám.

T15: Výpočetní technika (informační/digitální technologie) ve škole mi jen komplikuje život.

T16: Výpočetní techniku (informační/digitální technologie) ve své práci a ve výuce začnu používat až po př́islušném školení. 


\section{Průběh a výsledky výzkumu}

\section{1 Popis výzkumného vzorku}

V obou sledovaných fázích (letech) výzkum proběhl na základních školách Olomouckého kraje. Dotazníky byly rozeslány (př́ípadně osobně předány) do základních škol vesnických i městských s různým počtem žáků. V roce 2004 (Chráska, 2004) v první fázi srovnávacího výzkumu činil výzkumný vzorek 125 učitelů z 22 základních škol (oproti původnímu výzkumnému vzorku 145 učitelů byli pro srovnání vybráni pouze učitelé olomouckého regionu). Na každé škole bylo požádáno o spolupráci vždy co největší možné množství učitelů, aby ve výzkumném vzorku byly zastoupeny různé názorové hladiny.

Před provedením druhé fáze výzkumu byl ještě $\mathrm{v}$ roce 2014 proveden předvýzkum (Kosinová, 2014), kdy bylo osloveno více než 100 učitelů z 10 základních škol, ale vyplněných dotazníkủ bylo získáno pouze 38 . Ochota učitelů odpovídat, přesto, že jim byl vždy cíl výzkumu osobně vysvětlen, byla již v roce 2004 poměrně malá, v předvýzkumu v roce 2014 potom ještě menší. Výsledky předvýzkumu a prvotního srovnání uvádí publikace (Chráska, 2014).

V roce 2015 byla uskutečněna druhá fáze srovnávacího výzkumu. Celkem bylo ústně osloveno 350 učitelů druhého stupně základních škol, od nichž bylo získáno 85 vyplněných dotazníkủ. Složení výzkumného vzorku v obou etapách výzkumu uvádí tabulka 1.

Tabulka 1: Složení výzkumného vzorku v obou etapách výzkumu

\begin{tabular}{|c|c|c|c|c|}
\hline \multirow{2}{*}{ Etapa výzkumu } & \multicolumn{3}{|c|}{ Pohlaví } & Celkem \\
\cline { 2 - 4 } & (muž) & (̌̌ena) & (neuvedeno) & \\
\hline $\begin{array}{c}\text { I } \\
(\text { rok 2004) } \\
\begin{array}{c}\text { II } \\
\text { (rok 2015) }\end{array}\end{array}$ & 25 & 96 & 4 & 125 \\
\hline Celkem & 44 & 66 & 0 & 85 \\
\hline
\end{tabular}

\section{2 Výsledky srovnávacího výzkumu v roce 2004 a v roce 2015}

Souhrnné výsledky porovnání souhlasu učitelů s jednotlivými ekvivalentními tvrzeními v letech 2004 a 2015 je uvedeno v tabulce 2 a názorně je potom zobrazeno v grafu 1. Statistické srovnání v tab. 2 bylo provedeno pomocí Studentova t-testu. Ze zjištěných hodnot je patrné, že oproti roku 2004 došlo k pozitivnímu posunu v hodnocení informačních/digitálních technologií. Učitelé používají ICT významně častěji, více pracují s Internetem, více vyhledávají nové možnosti ICT, subjektivně hodnotí své dovednosti v oblasti ICT jako lepší, více spolupracují s ostatními učiteli pomocí počítačových sítí a obecně se snaží používat ICT více než v roce 2004.

Naopak oproti předvýzkumu z roku 2014 se nepotvrdilo, že by učitelé více potřebovali příslušná školení, což by mohlo souviset se stále větším používáním interaktivních tabulí i jiných složitějších elektronických pomůcek (např. e-učebnice, e-knihy apod.).

Podobně nebyly významné rozdíly zjištěny u souhlasu s tvrzeními T2, T5, T7, T9, T11, T15 a T16. 
Tabulka 2: Porovnání souhlasu učiteli s tvrzeními v letech 2004 a 2015 na škále 1-6 ( $1=$ vübec mne nevystihuje ... $6=$ zcela mne vystihuje)

\begin{tabular}{|c|c|c|c|c|}
\hline Tvrzení & 容志 & 눙 & $\omega$ & $=$ \\
\hline T1: Při své práci použivám Internet. & 4,07 & 4,86 & $-4,57$ & $<0,001$ \\
\hline $\begin{array}{l}\text { T2: Mám potíže s porozuměním novým } \\
\text { programům, které mi dovolují provádět takové } \\
\text { úkony, které jsem dosud nedělal(a). }\end{array}$ & 3,16 & 3,07 & 0,53 & 0,600 \\
\hline $\begin{array}{l}\text { T3: Nemám žádnou představu o využití výpočetní } \\
\text { techniky } \\
\text { technologií). }\end{array}$ & 2,04 & 1,72 & 2,16 & 0,032 \\
\hline $\begin{array}{l}\text { T4: Informace z oblasti využití výpočetní techniky } \\
\text { (informačních/digitálních technologií) umím } \\
\text { vyhledávat na Internetu. }\end{array}$ & 4,06 & 4,88 & $-5,07$ & $<0,001$ \\
\hline $\begin{array}{l}\text { T5: Mám problémy } \\
\begin{array}{l}\text { počítačům } \\
\text { technologiím). }\end{array}\end{array}$ & 3,10 & 2,78 & 1,82 & 0,070 \\
\hline $\begin{array}{l}\text { T6: Mám velmi dobré dovednosti v oblasti využití } \\
\text { výpočetní techniky (informačních/digitálních } \\
\text { technologií), dobře znám běžně používané } \\
\text { programy. }\end{array}$ & 3,57 & 4,34 & $-4,30$ & $<0,001$ \\
\hline $\begin{array}{l}\text { T7: Mám pocit, že v oblasti výpočetní techniky } \\
\text { (informačních/digitálních technologií) nejsou } \\
\text { žádné standardy. }\end{array}$ & 3,10 & 2,96 & 0,95 & 0,346 \\
\hline $\begin{array}{l}\text { T8: Neustále pracuji s lokálními a globálními } \\
\text { sítěmi s využitím Internetu. }\end{array}$ & 3,19 & 4,24 & $-5,60$ & $<0,001$ \\
\hline $\begin{array}{l}\text { T9: Rychlost a nezastavitelný vývoj v oblasti } \\
\text { výpočetní techniky (informačních/digitálních } \\
\text { technologií) mne frustruje. }\end{array}$ & 2,51 & 2,82 & $-1,67$ & 0,097 \\
\hline $\begin{array}{l}\text { T10: Neustále vyhledávám nové možnosti využití } \\
\begin{array}{l}\text { výpočetní } \\
\text { (informačních/digitálních technologií). }\end{array}\end{array}$ & 3,31 & 3,81 & $-2,83$ & 0,005 \\
\hline $\begin{array}{l}\text { T11: Pokud musím pracovat s výpočetní technikou } \\
\text { (informačními/digitálními technologiemi), } \\
\text { neustále žádám o technickou a mentální } \\
\text { podporu. }\end{array}$ & 2,95 & 2,66 & 1,65 & 0,100 \\
\hline $\begin{array}{l}\text { T12: Spolupracuji } \quad \text { s } \\
\text { prostřednictvím počítačových sítí. }\end{array}$ & 2,79 & 4,22 & $-7,63$ & $<0,001$ \\
\hline $\begin{array}{l}\text { T13: Př́i své práci se snažím vždy používat } \\
\text { výpočetní techniku (informační/digitální } \\
\text { technologie). }\end{array}$ & 3,62 & 4,45 & $-5,02$ & $<0,001$ \\
\hline $\begin{array}{l}\text { T14: Pokud jsou pro můj předmět } \mathrm{k} \text { dispozici } \\
\text { výukové programy, vždy je používám. }\end{array}$ & 3,54 & 4,31 & $-5,34$ & $<0,001$ \\
\hline
\end{tabular}




\begin{tabular}{|l|l|l|l|l|}
\hline $\begin{array}{c}\text { T15: Výpočetní technika (informační/digitální } \\
\text { technologie) ve škole mi jen komplikuje } \\
\text { život. }\end{array}$ & 2,06 & 2,04 & 0,13 & 0,894 \\
\hline $\begin{array}{c}\text { T16: Výpočetní techniku (informační/digitální } \\
\text { technologie) ve své práci a ve výuce začnu } \\
\text { používat až po př́slušném školení. }\end{array}$ & 2,45 & 2,20 & 1,44 & 0,152 \\
\hline
\end{tabular}

Pozn.: Signifikantní rozdíly jsou označeny tučně a kurzívou

\section{3 Identifikace typických skupin učitelů podle míry jejich souhlasu s jednotlivými předloženými tvrzeními}

Dále bylo zjištováno, zda se i v roce 2015 dají učitelé rozdělit, podle míry souhlasu s jednotlivými tvrzeními, do dvou typických skupin, stejně jako v roce 2004. Byla použita zobecněná shluková analýza, provedená pomocí programu STATISICA 12 CZ. Její výsledky jsou uvedeny v tab. 3 a v grafu 2 . Souhlas učitelů $\mathrm{s}$ jednotlivými tvrzeními byl navíc pro lepší interpretovatelnost v programu STATISTICA $12 \mathrm{CZ}$ standardizován, takže $0 \mathrm{v}$ grafu 2 znamená absolutní nesouhlas a 1 absolutní souhlas s daným tvrzením. Podobně to platí pro délku praxe ( 0 žádná praxe, 1 maximální praxe).

Identifikovaný shluk 1 - viz tab. 3 a graf 2 (cca $43 \%$ všech respondentů) tvoří učitelé s poněkud delší praxí (rozdíl však není významný), kteří oproti učitelům ze shluku 2 (cca $57 \%$ všech respondentů) při své práci používají ICT méně, mají častěji problémy s porozuměním novým programům a novým digitálním technologiím, méně vyhledávají informace na Internetu i nové možnosti využití ICT, méně spolupracují s ostatními učiteli pomocí sítí, ICT jim častěji komplikují život a budou je používat až po př́slušném školení a obecně mají problémy s tím, co doposud s ICT nedělali.

Zajímavé je, že pouze u souhlasu s tvrzením T7: Mám pocit, že v oblasti výpočetní techniky (informačních/digitálních technologií) nejsou žádné standardy, nebyly mezi identifikovanými skupinami (shluky) učitelů významné rozdíly.

Je tedy zřejmé, že stejně jako v roce 2004 (Chráska, 2004) je i v roce 2015 možné české učitele rozdělit do dvou typických skupin, z nichž jedna ICT více akceptuje, má o nich subjektivně lepší představu a častěji je použivá ve své výuce. Tato skupina u zkoumaných respondentů mírně převažuje (57\%). 
Tabulka 3: Zobecněná shluková analýza míry souhlasu učitelů s jednotlivými tvrzeními o práci s ICT v roce 2015

\begin{tabular}{|c|c|c|c|c|c|}
\hline \multirow[t]{2}{*}{ Tvrzení } & \multicolumn{2}{|c|}{$\begin{array}{l}\text { Míra souhlasu } \\
\text { s tvrzením }\end{array}$} & \multicolumn{2}{|c|}{$\begin{array}{l}\text { Standardizova- } \\
\text { ná míra } \\
\text { souhlasu } \\
\text { s tvrzením }\end{array}$} & \multirow[t]{2}{*}{$\begin{array}{l}\text { Signi- } \\
\text { ficance } \\
\mathrm{p}\end{array}$} \\
\hline & $\begin{array}{c}\text { Shluk } \\
1\end{array}$ & $\begin{array}{c}\text { Shluk } \\
2\end{array}$ & $\begin{array}{c}\text { Shluk } \\
1\end{array}$ & $\begin{array}{c}\text { Shluk } \\
2\end{array}$ & \\
\hline T1: Při své práci používám Internet. & 4,45 & 5,16 & 0,69 & 0,83 & 0,005 \\
\hline 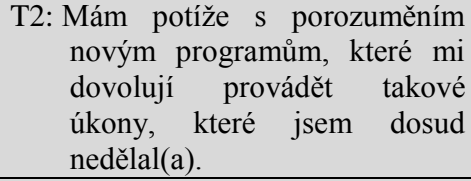 & 3,85 & 2,49 & 0,57 & 0,30 & $<0,001$ \\
\hline $\begin{array}{l}\text { T3: Nemám žádnou představu } \\
\text { o využití výpočetní techniky } \\
\text { (informačních/digitálních } \\
\text { technologií). } \\
\end{array}$ & 2,24 & 1,35 & 0,25 & 0,07 & $<0,001$ \\
\hline $\begin{array}{l}\text { T4: Informace z oblasti využití } \\
\text { výpočetní } \\
\text { (informačních/digitálních } \\
\text { technologií) umím vyhledávat } \\
\text { na Internetu. }\end{array}$ & 4,33 & 5,37 & 0,58 & 0,84 & $<0,001$ \\
\hline $\begin{array}{l}\text { T5: Mám problémy s porozuměním } \\
\text { novým počítačùm } \\
\text { (informačním/digitálním } \\
\text { technologiím). }\end{array}$ & 3,79 & 1,98 & 0,56 & 0,20 & $<0,001$ \\
\hline $\begin{array}{l}\text { T6: Mám velmi dobré dovednosti } \\
\text { v oblasti využití výpočetní } \\
\text { techniky } \\
\text { (informačních/digitálních } \\
\text { technologií), dobře znám běžně } \\
\text { používané programy. }\end{array}$ & 3,58 & 4,84 & 0,52 & 0,77 & $<0,001$ \\
\hline $\begin{array}{l}\text { T7: Mám pocit, že } \mathrm{v} \text { oblasti } \\
\text { výpočetní } \\
\text { (informačních/digitálních } \\
\text { technologií) nejsou žádné } \\
\text { standardy. }\end{array}$ & 3,12 & 2,81 & 0,53 & 0,45 & 0,104 \\
\hline $\begin{array}{l}\text { T8: Neustále pracuji s lokálními } \\
\text { a globálními sítěmi s využitím } \\
\text { Internetu. }\end{array}$ & 3,39 & 4,86 & 0,48 & 0,77 & $<0,001$ \\
\hline $\begin{array}{l}\text { T9: Rychlost a nezastavitelný vývoj } \\
\text { v oblasti výpočetní techniky } \\
\text { (informačních/digitálních } \\
\text { technologií) mne frustruje. }\end{array}$ & 3,70 & 2,16 & 0,54 & 0,23 & $<0,001$ \\
\hline
\end{tabular}




\begin{tabular}{|c|c|c|c|c|c|}
\hline $\begin{array}{l}\text { T10: Neustále vyhledávám nové } \\
\text { možnosti využití výpočetní } \\
\text { techniky } \\
\text { (informačních/digitálních } \\
\text { technologií). }\end{array}$ & 3,00 & 4,23 & 0,40 & 0,65 & $<0,001$ \\
\hline $\begin{array}{l}\text { T11: Pokud musím pracovat } \\
\text { s výpočetní } \\
\text { (informačními/digitálními } \\
\text { technologiemi), neustále } \\
\text { žádám o technickou } \\
\text { a mentální podporu. }\end{array}$ & 3,30 & 2,16 & 0,46 & 0,23 & $<0,001$ \\
\hline $\begin{array}{l}\text { T12: Spolupracuji s ostatními učiteli } \\
\text { prostřednictvím počítačových } \\
\text { sítí. }\end{array}$ & 3,82 & 4,53 & 0,56 & 0,71 & 0,004 \\
\hline $\begin{array}{l}\text { T13: Při své práci se snažím vždy } \\
\text { používat výpočetní techniku } \\
\text { (informační/digitální } \\
\text { technologie). }\end{array}$ & 3,82 & 4,91 & 0,45 & 0,73 & $<0,001$ \\
\hline $\begin{array}{l}\text { T14: Pokud jsou pro můj předmět } \\
\text { k dispozici výukové } \\
\text { programy, vždy je použivám. }\end{array}$ & 3,76 & 4,72 & 0,55 & 0,74 & $<0,001$ \\
\hline $\begin{array}{l}\text { T15: Výpočetní technika } \\
\text { (informační/digitální } \\
\text { technologie) ve škole mi jen } \\
\text { komplikuje život. }\end{array}$ & 2,76 & 1,53 & 0,35 & 0,11 & $<0,001$ \\
\hline $\begin{array}{l}\text { T16: Výpočetní } \\
\text { (informační/digitální techniku } \\
\text { technologie) ve své práci a ve } \\
\text { výuce začnu použivat až po } \\
\text { př́slušném školení. }\end{array}$ & 2,76 & 1,86 & 0,44 & 0,22 & $<0,001$ \\
\hline Délka praxe & 8,70 & 7,41 & 0,29 & 0,25 & 0,377 \\
\hline Počet př́ípadů & 33 & 43 & & & \\
\hline Procentuální zastoupení & 43,42 & 56,58 & & & \\
\hline
\end{tabular}




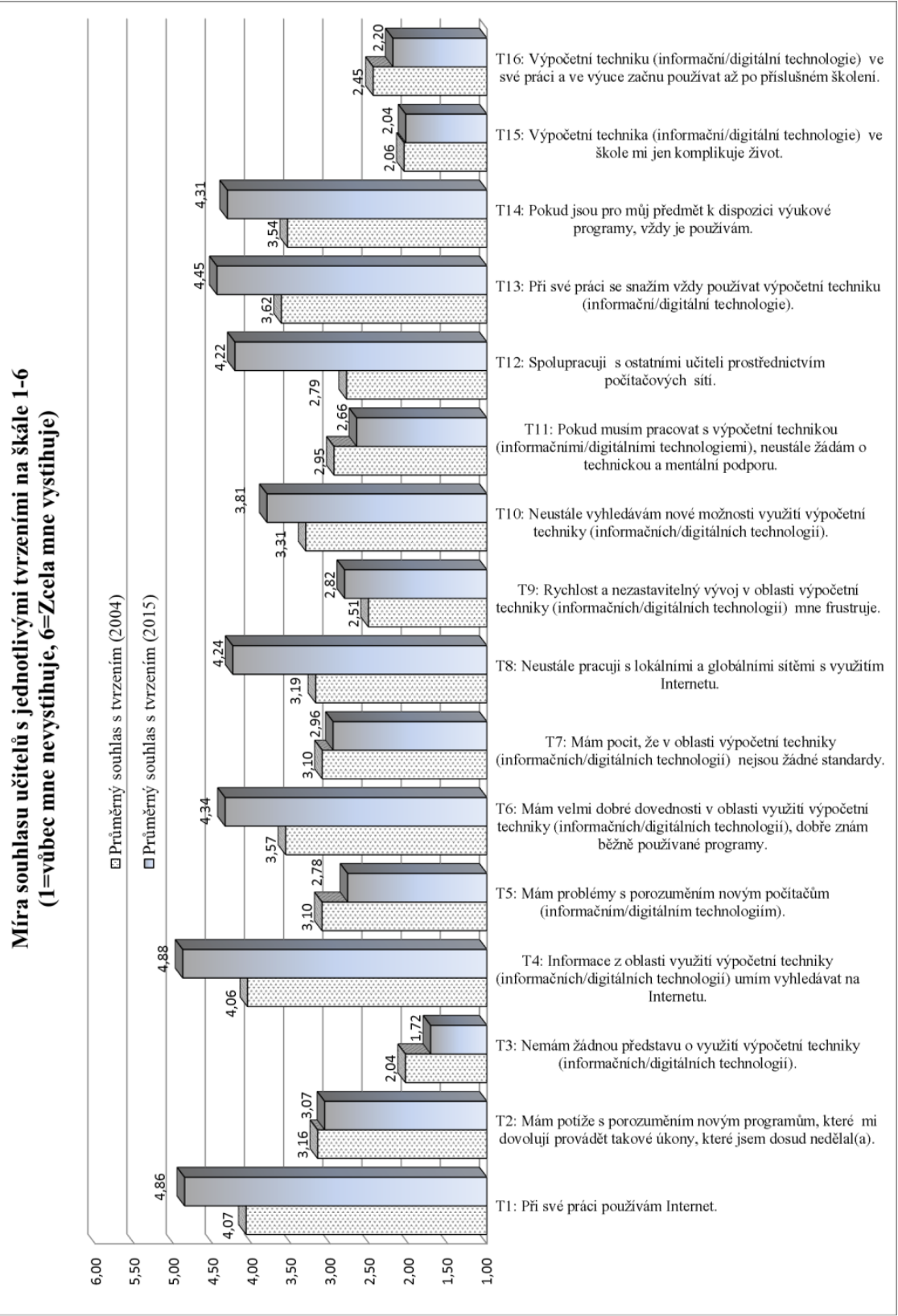

Graf 1: Porovnání souhlasu učitelů s jednotlivými tvrzeními v roce 2004 a 2015 


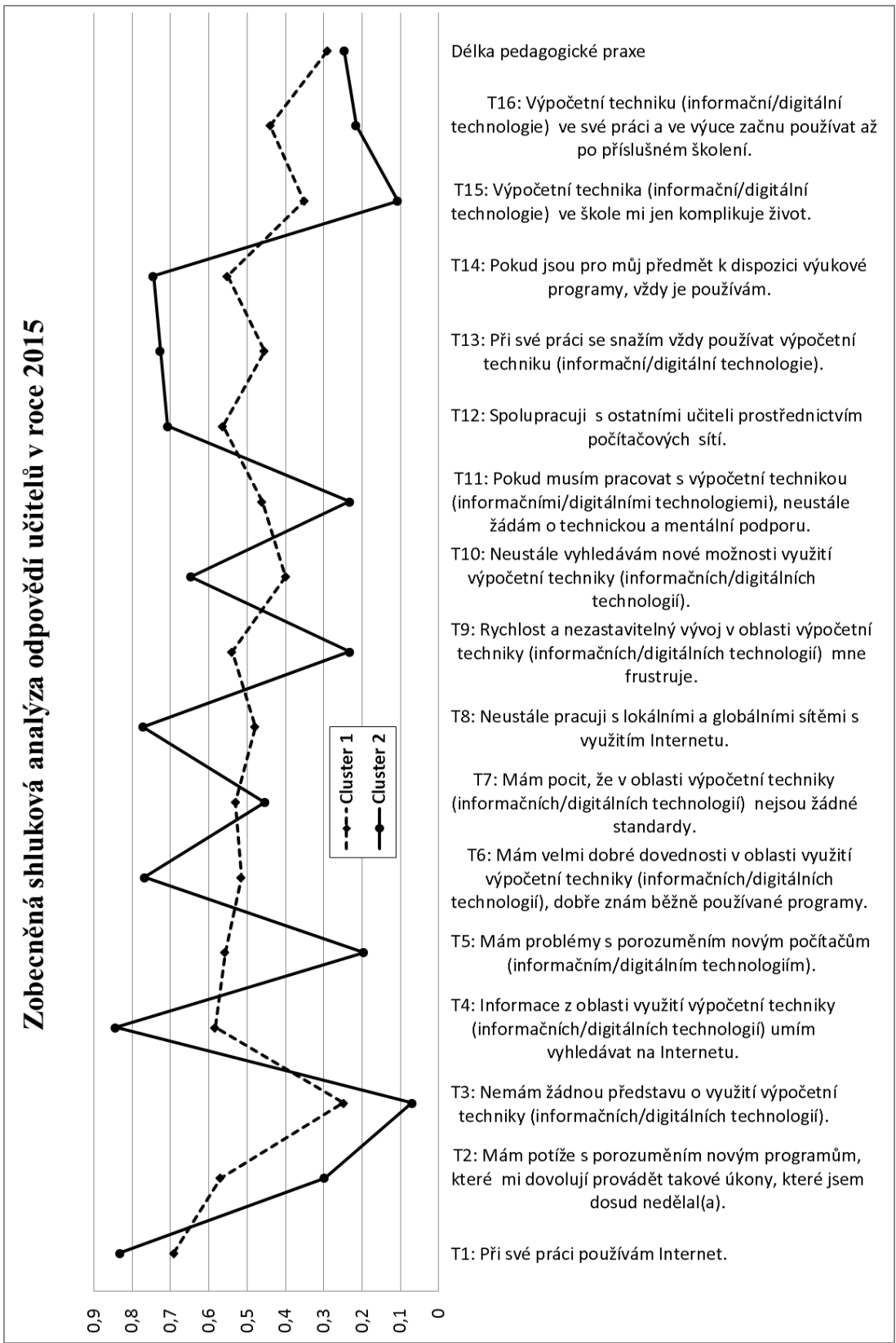

Graf 2: Zobecněná shluková analýza odpovědi učitelì v roce 2015 


\section{Diskuze a závěry}

Z provedeného srovnávacího výzkumu vyplynulo, že oproti roku 2004 došlo u učitelů na 2. stupni ZŠ k pozitivnímu posunu $\mathrm{v}$ hodnocení informačních/digitálních technologií. Učitelé používají ICT významně častěji, více pracují s Internetem, více vyhledávají nové možnosti ICT, subjektivně hodnotí své dovednosti voblasti ICT jako lepší, více spolupracují s ostatními učiteli pomocí počítačových sítí a obecně se snaží používat ICT více než v roce 2004.

Dále bylo také zjištěno, že stejně jako v roce 2004, můžeme učitele podle jejich souhlasu $\mathrm{s}$ jednotlivými předkládanými tvrzeními, týkajících se způsobu jejich práce s ICT, i v roce 2015 rozdělit o dvou navzájem odlišných skupin (shluků).

Zákonitě se nabízí otázka, zda tyto „shluky“ učitelů nejsou shodné s tzv. digitálními domorodci a imigranty, definovanými Prenským (Prenský, 2001). Digitální domorodci jsou definování jako lidé, kteří od raného dětství vyrůstají v prostředí bohatém na moderní technologie, jako jsou počítače, digitální hudební přehrávače, videokamery, webkamery, mobilní telefony apod. Jsou zvyklí přijímat informace velmi rychle, dávají přednost současně probíhajícím aktivitám, spolupracují na síti, rozdílně myslí a zpracovávají informace. Digitální imigranti jsou naopak podle tohoto př́stupu př́slušníci starších generací, kteří se s výše uvedenými technologickými nástroji setkali až ve vyšším věku. Technologie jsou tedy pro ně něčím novým, nepřirozeným a někdy i nadbytečným.

Z výsledků výzkumu je však také patrné, že zjištěné rozdíly mezi identifikovanými shluky učitelů nebyly ovlivněny délkou jejich praxe. Je tedy nepravděpodobné, že by ve zkoumaném vzorku učitelů existovalo takto striktní dělení v závislosti na věku. Je spíše pravděpodobné, že učitelé mají tendenci se dělit do dvou odlišných skupin podle míry jejich osobní preference ICT. $V$ další analýze dat $\mathrm{z}$ výzkumu se proto chceme dále zaměřit na další zjištované intervenující proměnné jako: názor na nebytnost informačních/digitálních technologií, jejich vhodnost pro žáky, negativní působení technologií, způsob a četnost využití technologií jednotlivými učiteli, genderová podmíněnost, možný vliv vystudovaného oboru a osobní charakteristika učitele vzhledem k používání informačních/digitálních technologií.

Příspěvek vznikl v rámci řešení projektu CZ.1.07/2.3.00/20.0166 Centrum teorie vzdělávání př́írodovědných oborů. 


\section{Literatura}

Černochová, M., Siňor, S., Kankaarinta, I.A. (2001). Jak budoucí učitelé přijímají novinky ze světa informačních a komunikačních technologií. In Nové možnosti vzděláváni a pedagogický výzkum. Ostrava: Ostravská univerzita. s. 330-336. ISBN 80-7042$181-9$.

Fraillon, J., Ainley, J., Schulz, W., Friedman, T., Gebhardt, E. (2014). Preparing for Life in a Digital Age. The IEA International Computer and Information Literacy Study International Report. Cham, Heidelberg, New York, Dordrecht, London: Springer. ISBN 978-3-319-14221-0.

Chráska, M. (2004). Typologie učitelů podle způsobu práce s ICT. In XVII. DIDMATTECH 2004. TECHNIKA-INFORMATYKA-EDUKACJA. Rzeszów: FOSZE. s. 320-324. ISBN 83-88845-39-X.

Chráska, M. (2014). Porovnání vztahu učitelů k informačním a komunikačním technologiím mezi roky 2004 a 2014. Edukacja-Technika-Informatyka. Roč. 5/2014, č. 2, s. 48-53. ISSN 2080-9069.

Kosinová, V. (2014). Učitel vzdělávací oblasti "Informační a komunikačni technologie" a jeho pojetí výuky. Bakalářská práce. Olomouc: PdF UP. 52 s., 10 1. př́l. Vedoucí práce Miroslav Chráska.

Law, N., Chow, A. and Yuen, A.H.K. (2005). Methodological approaches to comparing pedagogical innovations using technology. Education and Information Technologies, 10(1-2), pp. 5-18. ISSN 1360-2357.

Law, N., Pelgrum, W.J., \& Plomp, T. (Eds.). (2008). Pedagogy and ICT use in schools around the world: Findings from the IEA SITES 2006 study. Hong Kong: CERCSpringer. ISBN 978-1-4020-8928-2.

Maria Mama, T. and Hennessy, S. (2013). Developing a typology of teacher beliefs and practices concerning classroom use of ICT. Computers and Education, 68, pp. 380387. ISSN 0360-1315.

Prensky M. (2001). Digital Natives, Digital Immigrants. On the horizon [online]. Vol. 9, no. 5, ISSN 1074-8121. Dostupné z: http://www.marcprensky.com/writing/Prensky\%20\%20Digital\%20Natives,\%20Digital\%20Immigrants\%20-\%20Part1.pdf

Tubin, D. 2012. Typology of ICT implementation and technology applications. Type II Uses of Technology in Education: Projects, Case Studies, and Software Applications. pp. 85-98. ISBN 978-020305167-2.

Webster, T.E. and Son, J. (2015). Doing what works: A grounded theory case study of technology use by teachers of English at a Korean university. Computers and Education, 80, pp. 84-94. ISSN 0360-1315.

Zounek, J., Šed’ová, K. (2009). Učitelé a technologie: mezi tradičním a moderním pojetím. Brno: Paido. ISBN 978-80-7315-187-4. 